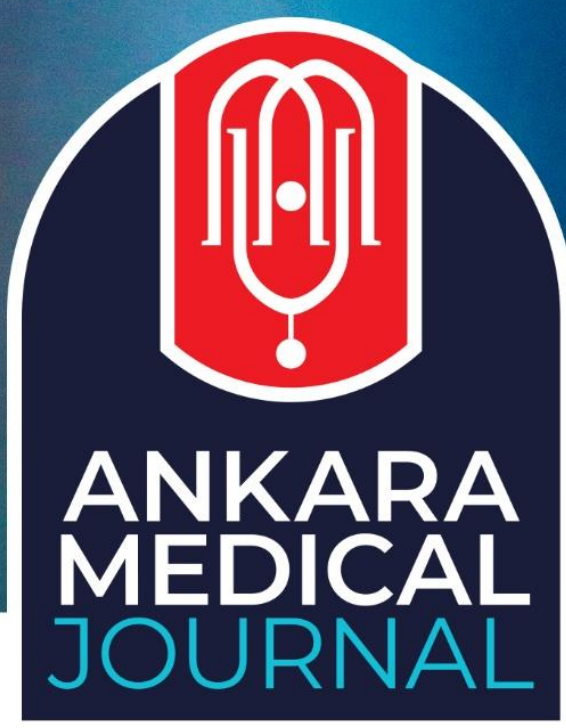

Research Article

Ankara Med J, 2021;(4):585-593 // (đi) 10.5505/amj.2021.70846

\title{
EVALUATION OF HEADACHE CHARACTERISTICS IN PATIENTS PRESENTING WITH SUSPECTED COVID-19
}

\section{COVID-19 ŞÜPHESIYYE BAŞVURAN HASTALARDA BAŞ AĞRISI ÖZELLİKLERİNİN DEĞERLENDİRİLMESİ}

(i) Özgül Ocak¹, (D) Erkan Melih Şahin²

${ }^{1}$ Çanakkale Onsekiz Mart Üniversitesi Tıp Fakültesi Nöroloji AD, Çanakkale

${ }^{2}$ Çanakkale Onsekiz Mart Üniversitesi Tıp Fakültesi Aile Hekimliği AD, Çanakkale

Yazışma Adresi / Correspondence:

Erkan Melih Şahin (e-posta: emsahin@yahoo.com)

Geliş Tarihi: 04.04.2021 // Kabul Tarihi: 26.10.2021

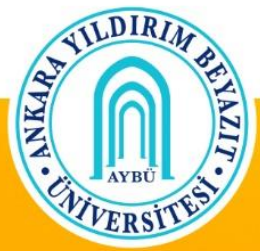

Ankara Y.ldırım Beyazıt University Faculty of Medicine 


\title{
Öz
}

Amaç: Bu çalışmada COVID-19 enfeksiyonunda baş ağrısı sıklığını ve hastalığa özgü olup olmadığını belirlemek amaçlanmıştır.

Materyal ve Metot: Kesitsel tanımlayıcı araștırmaya COVID Polikliniğine başvuran 18 yaş üstü tüm hastalar dahil edilmiştir. Hastalardan baş ağrısı şikayeti varlığı ve özelliklerine yönelik 18 soru yanıtlamaları istenmiştir. Bağ ağrısı tanı gruplarını ayırmak için ID MIGREN ölçeği ve Uluslararası Baş Ağrısı Cemiyeti tanı kriterleri, ağrı yoğunluğu için Vizüel Ağrı Skalası kullanılmıştır.

Bulgular: Çalışma 440 katılımcıdan 208'i $(\% 47,27)$ kadındı. 273 ilk başvuru hastasından 44'ünde $(\% 16,12)$ pozitif RT-PCR sonucu alınmıștı. Başvuruları herhangi bir şikayete dayalı olan 301 hastadan 179'unun $(\% 59,47)$ baş ağrısı şikayetleri bulunuyordu. VAS'a göre ağrı yoğunluğu 5,86 $\pm 2,72$ idi. Baş ağrısı bulunma oranları ya da ağrı yoğunluğu RT-PCR test sonuçları açısından anlamlı farklılık göstermiyordu. Baş ağrısı tanı grupları açısından RT-PCR test sonuçlarına göre anlamlı farklılık yoktu.

Sonuç: Baş ağrısı COVID-19 hastalarında en sık yakınmalardan biridir. Çalışmamızda COVID-19 polikliniğine hastalık şüphesi ile başvuran hastalardan RT-PCR testi ile tanı alan ve almayan hastalar arasında baş ağrısı şikayetinin sıklık ve özelliklerinde farklılık yoktur.

Anahtar Kelimeler: COVID-19, baș ağrısı, migren, COVID-19 RT-PCR testi.

\begin{abstract}
Objectives: This study aimed to determine the frequency of headaches in COVID-19 related hospital admissions and whether they are specific to the disease.

Materials and Methods: All patients over the age of 18 who applied to the COVID Outpatient Clinic were included in the cross-sectional descriptive study. Patients were asked to answer an 18-item questionnaire about the presence and characteristics of headache complaints. The ID Migraine scale and International Headache Society diagnostic criteria were used for classification, and the visual Pain Scale was used for pain intensity.

Results: Of the 440 participants, 208 (47.27\%) were women. Of the 273 first applicant patients, 44 (16.12\%) had positive RT-PCR results. Of the 301 patients whose applications were based on any complaint, 179 $(59.47 \%)$ had headaches. According to VAS, the pain intensity was $5.86 \pm 2.72$. Rates of headache presence or pain intensity did not differ in terms of RT-PCR test results. There was no significant difference in headache diagnostic groups according to RT-PCR test results.

Conclusion: A headache is one of the most common complaints in COVID-19 patients. In our study, there was no difference in the frequency and characteristics of headaches according to RT-PCR test among patients who applied to the COVID-19 outpatient clinic with suspicion of the illness.

Keywords: COVID-19, headache, migraine headache, COVID-19 RT-PCR testing.
\end{abstract}




\section{Introduction}

A headache is one of the most common complaints among reasons for admission to neurology outpatient clinics. For this reason, providing an accurate diagnosis as well as effective and quick treatment is important. As stated in many publications during the COVID-19 pandemic, a headache is a common neurological finding for the disease.

In the retrospective observational study in China by Mao et al., of neurological symptoms present in $36.4 \%$ of 214 patients diagnosed with COVID-19, headaches were detected at a high rate of $13.1 \%$. Neurological symptoms were observed at a higher rate, especially in older cases, more prone to comorbid conditions, and with severe respiratory system involvement. ${ }^{1-2}$ In a study evaluating neurological symptoms in hospitalized COVID-19 patients in Italy, tension headaches were observed. ${ }^{3}$ In clinical observations and small case series, headaches related to COVID-19 have been described as acute onset and usually have a different character than preexisting headaches. ${ }^{4-5}$ These headaches are often bilateral. ${ }^{6}$ The coexistence of COVID-19 infection and cerebral sinus vein thrombosis presenting with a severe headache in a 59-year-old patient with a history of obesity, smoking, hypertension, and diabetes has also been reported. ${ }^{7}$

The study aims to determine the prevalence and characteristics of headaches in patients admitted to the COVID-19 outpatient clinics of Çanakkale Onsekiz Mart University Hospital and the changes in headaches that previously existed in patients during this period.

\section{Materials and Methods}

In this cross-sectional descriptive study, informed consent was obtained from all participants. The data collection phase of the study was carried out between December 21, 2020 and January 22, 2021. Adult patients (18 years of age and above) who applied to Çanakkale Onsekiz Mart University Hospital COVID Outpatient Clinic were invited to join the study.

Patients who gave consent were asked to complete the data form created for the study. The links to the online forms prepared to reduce personal contact were sent to the mobile phones of the participants. Data forms were filled in by the participants in the waiting rooms. The real-time polymerase chain reaction (RT-PCR) test was applied for COVID-19 disease confirmation.

The data form was developed by the study researchers. The first part requested sociodemographic data, while the second part included questions about headaches. There were 18 questions about headaches, including the 
3-question ID Migraine scale, the one-question Visual Pain Scale (VAS) and other questions to define headache characteristics.

\section{ID Migraine Test}

It was developed by Lipton et al.in the United States in 2003 to facilitate the diagnosis of migraine patients, especially in primary healthcare units. ${ }^{8}$ The Turkish version of the test was developed by Siva et al. In studies conducted in primary care, the sensitivity of the ID Migraine Test was $81 \%$, specificity $75 \%$, and positive predictive value 93\%. The Turkish version of the Identity Migraine Test has been accepted as valid. ${ }^{9}$

The International Headache Society diagnostic criteria were used to define other types of headaches. ${ }^{10}$ Information on the COVID-19 disease processes of the patients was obtained through the hospital registration system.

\section{Statistical analysis}

Collected data were digitalized and corrected; descriptive information is presented as the frequencies and percentages for categorical data, and with mean and standard deviation for ordinal data. Since the sample number was larger than 30, the normal distribution assumption of parametric tests was ignored based on the central limit theorem. The primary headache diagnosis of the patients was determined according to the questions about headaches, and headache characteristics were analyzed in terms of COVID-19 disease outcomes and demographic characteristics with Chi-square, Student t, and Pearson correlation tests. When the expected value was less than five, Fisher's exact test result was reported. Test constants and absolute p values are presented for all analyses, and $\mathrm{p}<0.05$ was accepted as the general significance limit.

\section{Results}

The study consisted of data from 440 participants. 232 (52.72\%) of the participants were male, 208 (47.28\%) were female, and their average age was $40.81 \pm 15.42$ (minimum 18, maximum 88). Of the participants, 273 (62.05\%) were first applicants, and 167 (37.95\%) were control visits. One hundred thirty-nine of the participants (31.59\%) had no complaints, and their applications were for various administrative reasons. The real-time polymerase chain reaction (RT-PCR) test was applied to 288 of the patients whose applications were based on any complaint, and 77 positive results were obtained.

Of the 301 patients whose applications were based on any complaint, 179 (59.47\%) had headaches. Headache was present in 49 (51.04\%) out of 96 control visits and in $130(63.41 \%)$ of 205 primary visits, and the rate of headache at first admission was significantly higher than in control interviews $\left(X^{2}=4.153 ; p=0.042\right)$. 
RT-PCR test was applied to 173 patients with headaches. Headache complaints were present in 43 (55.84\%) of 77 patients with positive RT-PCR tests and $130(61.61 \%)$ of 211 negative patients. The rates of headache presence did not differ significantly in terms of RT-PCR test results $\left(X^{2}=0.782 ; p=0.376\right)$.

The presence of headaches did not differ significantly in terms of gender $\left(X^{2}=2.598 ; p=0.107\right)$. The mean age of those who reported having headaches $(36.88 \pm 12.94)$ was significantly lower than the age of those who did not $(43.94 \pm 15.36)(\mathrm{t}=4.172 ; \mathrm{p}<0.001)$. The presence of headaches differed significantly in terms of working status $\left(X^{2}=16.182 ; p=0.001\right)$. It was significantly lower in those who were not working (housewives, students, etc.) and retirees. The presence of headaches differed significantly in terms of smoking status $\left(X^{2}=8.010\right.$; $\mathrm{p}=0.018$ ), with the rate of headache being higher in active smokers. The presence of headache complaints did not differ significantly in terms of alcohol use $\left(X^{2}=5.058 ; \mathrm{p}=0.080\right)$.

Headaches started on admission to the COVID clinic for 94 participants, increased during this period for 42 participants, reappeared for 18, and previous headaches continued for12 participants among 166 valid responses. As for the duration of headache complaints, 25 participants reported one day, 49 participants two days, 40 participants three days, 13 participants four days, 16 participants five days, and 26 participants more than five days.

Characteristic features of headaches according to RT-PCR test results are presented in Table 1. When patients were asked to numerically rate the intensity of their headaches between 0 (no pain) and 10 (the most severe pain in my life), the mean intensity for 177 valid responses was $5.86 \pm 2.72$. Pain intensity was not significantly different according to the RT-PCR test result $(\mathrm{t}=1.883 ; \mathrm{p}=0.061)$.

Of the 179 participants who reported having headaches, 98 (54.75\%) had positive ID Migraine tests. According to the classification made using the International Headache Society diagnostic criteria, there were seven (3.91\%) patients with tension headaches and 27 (15.08\%) patients with trigeminal autonomic headaches. More than one primary headache was observed in 20 of the patients. In 67 (37.43\%) patients who reported having headaches, the complaints did not meet any specific criteria. Headache incidence rates according to RTPCR test results are shown in Table 2.

The ID Migraine test result was not significantly different between the primary admission and control visits $\left(X^{2}=1.142 ; p=0.285\right)$. ID Migraine test results were positive in 23 (53.49\%) of 43 patients with positive RTPCR test results and 70 (53.85\%) of 130 negative patients. The ID Migraine test result did not show a significant difference in terms of RT-PCR test results $\left(X^{2}=0.002 ; \mathrm{p}=0.967\right)$. When only the first applications were evaluated, the ID Migraine test result did not show a significant difference in terms of RT-PCR test results $\left(X^{2}=1,350\right.$; $\mathrm{p}=0.245)$. The rate of those with positive ID Migraine test results was significantly higher in females (67.65\%) 
than males $(37.66 \%)\left(X^{2}=15.923 ; \mathrm{p}<0.001\right)$. Mean ages were not significantly different in terms of ID Migraine test results ( $\mathrm{t}=0.082 ; \mathrm{p}=0.935)$.

There was no significant difference according to RT-PCR test results for the diagnosis of tension headaches $\left(X^{2}=2.413 ; p=0.195\right)$, or trigeminal autonomic headaches $\left(X^{2}=0.390 ; p=0.532\right)$. Those who did not meet specific diagnostic criteria had no significant differences according to RT-PCR test results $\left(X^{2}=0.259 ; p=0.611\right)$.

Table 1. Characteristic features of headache according to RT-PCR test results

\begin{tabular}{|c|c|c|c|}
\hline & RT-PCR (+) & RT-PCR (-) & Statistical values \\
\hline $\begin{array}{l}\text { The location of the pain** } \\
\text { same half of the head } \\
\text { changing half of the head } \\
\text { both halves of the head }\end{array}$ & $\begin{array}{c}10(25.64 \%) \\
8(20.51 \%) \\
21(53.85 \%)\end{array}$ & $\begin{array}{l}25(22.32 \%) \\
19(16.96 \%) \\
68(60.72 \%)\end{array}$ & $X^{2}=0.573 ; p=0.751$ \\
\hline $\begin{array}{l}\text { Duration of headaches } * * * \\
\text { less than } 1 \text { min. } \\
1-30 \text { min. } \\
\text { longer than } 30 \text { min. } \\
\text { longer than } 4 \text { hours } \\
\text { longer than } 3 \text { days }\end{array}$ & $\begin{array}{c}2(4.88 \%) \\
15(36.59 \%) \\
9(21.95 \%) \\
11(26.83 \%) \\
4(9.76 \%) \\
\end{array}$ & $\begin{array}{c}6(5.08 \%) \\
34(28.81 \%) \\
34(28.81 \%) \\
33(27.97 \%) \\
11(9.32 \%) \\
\end{array}$ & $\mathrm{X}^{2}=1.271^{*} ; \mathrm{p}=0.886$ \\
\hline $\begin{array}{c}\text { Character of pain } * * * * \\
\text { Throbbing }\end{array}$ & $30(6977 \%)$ & $75(5769 \%)$ & $\mathrm{X}_{2}^{-1} 975 \cdot n-0160$ \\
\hline Compressing & $5(11.63 \%)$ & $36(27.69)$ & $X^{2}=4.611 ; p=0.032$ \\
\hline Stabbing & $7(16.28 \%)$ & $21(16.15 \%)$ & $\mathrm{X}^{2}=0.0004 ; \mathrm{p}=0.985$ \\
\hline lightning like & $2(4.65 \%)$ & $10(7.69 \%)$ & $\mathrm{X}^{2}=0.502 * ; \mathrm{p}=0.732$ \\
\hline Accompanying nausea & $20(47.62 \%)$ & $60(49.18 \%)$ & $\mathrm{X}^{2}=0.030 ; \mathrm{p}=0.861$ \\
\hline Accompanying vomiting & $7(16.67 \%)$ & $21(17.36 \%)$ & $\mathrm{X}^{2}=0.010 ; \mathrm{p}=0.919$ \\
\hline Disturbed by light or noise & $27(64.29 \%)$ & $81(66.39 \%)$ & $X^{2}=0.062 ; p=0.804$ \\
\hline $\begin{array}{l}\text { Exacerbated pain by physical activity such as } \\
\text { climbing stairs }\end{array}$ & $18(45.00 \%)$ & $51(43.22 \%)$ & $\mathrm{X}^{2}=0.038 ; \mathrm{p}=0.845$ \\
\hline Pain intensity (VAS scale) & $6.52 \pm 2.42$ & $5.61 \pm 2.82$ & $\mathrm{t}=1.883 ; \mathrm{p}=0.061$ \\
\hline
\end{tabular}

*Fisher's exact test

**Patients who defined other than the specified characteristics were excluded.

*** There are patients who do not respond

**** Patients could have selected more than one feature 
Table 2. Headache incidence rates and intensity according to RT-PCR test results

\begin{tabular}{|l|c|c|c|}
\hline & RT-PCR (+) & RT-PCR (-) & Statistical values \\
\hline Migraine & $23(53.49 \%)$ & $70(53.85 \%)$ & $\mathrm{X}^{2}=0.002 ; \mathrm{p}=0.967$ \\
\hline Tension Headache & $0(0.00 \%)$ & $7(5.38 \%)$ & $\mathrm{X}^{2}=2.413 ; \mathrm{p}=0.195$ \\
\hline Trigeminal Autonomic Headache & $8(18.60 \%)$ & $19(14.62 \%)$ & $\mathrm{X}^{2}=0.390 ; \mathrm{p}=0.532$ \\
\hline $\begin{array}{l}\text { Headache not meeting any specific } \\
\text { diagnostic criteria }\end{array}$ & $15(34.88 \%)$ & $51(39.23 \%)$ & $\mathrm{X}^{2}=0.259 ; \mathrm{p}=0.611$ \\
\hline TOTAL (Any headache) & $43(100.00 \%)$ & $130(100.00 \%)$ & $\mathrm{X}^{2}=0.782 ; \mathrm{p}=0.376$ \\
\hline
\end{tabular}

RT-PCR: real time polymerase chain reaction test. VAS: visual analog scale

* More than one primary headache diagnostic criteria were met in 20 of the patients.

\section{Discussion}

Systemic viral infections may cause headaches in the absence of meningitis or encephalitis, and a headache that occurs temporally in connection with the infection is included in the ICHDIII classification as a separate title. ${ }^{10}$

Headache is a common symptom in the COVID-19 disease. In a China-based meta-analysis where the clinical findings of 3,600 patients were compiled, the prevalence of headache in COVID-19 patients was reported as $14 \%{ }^{11}$ In another European-based study in which the clinical findings of 1,420 COVID-19 patients were reported, a headache was the most common symptom with a rate of $70.3 \% .{ }^{12}$ In a review by Lippi et al., rates of headache were examined in the studies on COVID-19 in the literature, and it was found that the frequency of headache ranged from $6.5 \%$ to $40 \%{ }^{13}$ In a meta-analysis where 38 studies, including a total of 3,062 COVID19 patients in China, were included, the headache was expressed as a minor symptom and was defined in $15.4 \%$ of the cases. ${ }^{14}$ In another meta-analysis in which 60 studies were reviewed, the symptoms of 59,254 patients from 11 countries were compiled, and the headache was reported as the fifth most common complaint in $12 \%$ of patients after fever, cough, muscle aches and dyspnea. ${ }^{15}$ In approximately 6-10\% of symptomatic COVID-19 patients, headache has also been reported as a complaint at the presentation of the disease. ${ }^{4}$ Headache in Coronavirus disease is mostly defined together with fever and may be related to it. ${ }^{1}$

Although the pathogenesis of headaches observed in COVID-19 cases is not fully explained, it is thought that three different mechanisms may cause headaches. Accordingly, it is thought that headaches may be associated with proinflammatory mediators and cytokines released due to the virus or that the trigeminal nerve endings in the nasal cavity are directly affected by the virus and may trigger headaches. In addition to

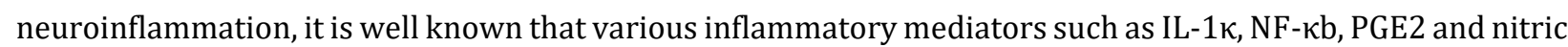
oxide play a role in trigeminovascular activation. ${ }^{16}$ Finally, it is thought that the trigeminovascular pathway activated by the involvement of endothelial cells rich in Angiotensin-Converting Enzyme 2 (ACE2) expression may trigger headaches. ${ }^{4}$ The involvement of endothelial cells with high ACE2 expression in vascular pathogenesis may be a factor in trigeminovascular activation leading to headaches. ACE2 antigen, which forms 
the entry route of the COVID-19 virus into the body, has been shown not only in respiratory epithelial cells but also in many different tissues such as gastrointestinal epithelial cells, endothelial cells and the heart. The virus is observed in endothelial cells with signs of widespread endothelial inflammation. ${ }^{17}$

The relationship of headaches in post-infectious disease is not well covered in the literature. Various postinfectious central nervous system (CNS) disorders can have a headache as one of the accompanying symptoms. However, headache as an isolated or post-infectious disease has not been sufficiently explored in the literature. ${ }^{18}$

Many neurological signs, including headaches, have been reported during the COVID-19 disease. Studies have shown high incidence rates of headaches in COVID-19 patients. In our study, the frequency and characteristics of headaches as the presenting complaint was determined by screening patients who applied with suspicion of illness. The diagnosis of COVID-19 was confirmed by the RT-PCR test. Consistent with other studies, in our study, it was shown that a headache is a common symptom, seen in 55.8\% of COVID-19 patients. On the other hand, the incidence of headaches, pain intensity and specific headache diagnoses in COVID-19 patients do not differ from other patients presenting with disease suspicion. In other words, no disease-specific feature of the headaches observed in COVID-19 patients was detected. Characteristics of COVID-19 patients who develop headaches, geographical differences in the prevalence of these headaches, and features in COVID-19 variants are areas still worthy of research.

\section{Ethical Considerations}

Ethics committee approval was obtained for the study from Çanakkale Onsekiz Mart University Ethics Committee for Clinical Studies with decision number 14-17 dated December 09, 2020. All the procedures followed were in accordance with the ethical standards of the ethics committee and with the Helsinki Declaration of 1975, as revised in 2000.

\section{Conflict of Interest}

The authors declare no conflict of interest. 


\section{References}

1. Mao L, Jin H, Wang M, Hu Y, Chen S, He Q, et al. Neurologic manifestations of hospitalized patients with Coronavirus Disease 2019 in Wuhan, China. JAMA Neurol 2020;77(6):683-90. (doi:10.1001/jamaneurol.2020.1127)

2. Wang D, Hu B, Hu C, Zhu F, Liu X, Zhang J,et al. Clinical characteristics of 138 hospitalized patients with 2019 novel Corona virus-infected pneumonia in Vuhan, China. JAMA 2020;323:1061-9. (doi:10.1001/jama.2020.1585)

3. Vacchiano V, Riguzzi P, Volpi L, Tappata M, Avoni P, Rizzo G,et al. Early neurological manifestations of hospitalized COVID-19 patients. NeurolSci 2020;41:2029-31. (doi:10.1007/s10072-020-04525-z)

4. Bolay H, Gul A, Baykan B. COVID-19 is a real headache! Headache 2020;60:1415-21.(doi: 10.1111/head.13856)

5. Toptan T, Aktan C, Basari A, Bolay H. Case series of headache characteristics in COVID-19; headache can be an isolated symptom. Headache 2020;60(8):1788-92. (doi:10.1111/head.13940)

6. Karadas O, Ozturk B, Sonkaya AR. A prospective clinical study of detailed neurological manifestations in patients with COVID-19. Neurol Sci 2020;41(8):1991-5. (doi:10.1007/s10072-020-04547-7)

7. Hughes C, Nichols T, Pike M, Subbe C, Elghenzai S. Cerebralvenoussinusthrombosis as a presentation of COVID-19. Eur J Case Rep Intern Med 2020;7(5):001691. (doi:10.12890/2020_001691)

8. Lipton RB, Dodick D, SadovskyR, KolodnerK, EndicottJ, Hettiarachchi J. A self-administered screener for migraine in primary care: theIDmigrainevalidationstudy. Neurology2003;61(3):37582.(doi:10.1212/01.wnl.0000078940.53438.83)

9. Siva A, Zarifoğlu M. Validity of the Turkish ID Migrainescreener in workers and the impact of migraine on productivity. Cephalalgia2005;25:863-5.

10. HeadacheClassificationCommittee of the International Headache Society (IHS). The international classification of headache disorders, 3rd edition. Cephalalgia 2018;38:1-211. (doi:10.1177/0333102417738202)

11. Wu Y, Xu X, Chen Z, Duan J, Hashimoto K, Yang L, et al. Nervous system involvement after infection with COVID-19 and other coronaviruses. Brain Behav Immun 2020;87:18-22. (doi:10.1016/j.bbi.2020.03.031)

12. Lechien JR, Chiesa-Estomba CM, Place S, Van Laethem Y, Cabaraux P, Mat Q,et al. Clinical and epidemiological characteristics of 1,420 European patients with mild to-moderate Corona virus Disease 2019. J InternMed 2020;288(3):335-44. (doi:10.1111/joim.13089)

13. Lippi G, Mattiuzzi C, Bovo C, Henry BM. Headache is an important symptom in patients with corona virus disease 2019 (COVID-19). Diagnosis (Berl) 2020;7(4):409-11. (doi:10.1515/dx-2020-0048) 
14. Zhu J, Ji P, Pang J, Zhong Z, Li H, He C, et al. Clinical characteristics of 3062 COVID-19 patients: A metaanalysis. J MedVirol 2020;92(10):1902-14. (doi:10.1002/jmv.25884)

15. Borges do Nascimento IJ, Cacic N, Abdulazeem HM, vonGroote TC, Jayarajah U, Weerasekara I, et al. Novel Coronavirus Infection (COVID-19) in humans: a scoping review and meta-analysis. J ClinMed 2020;9(4):941. (doi:10.3390/jcm9040941)

16. Edvinsson L, Haanes KA, Warfvinge K. Does inflammation have a role in migraine? Nat Rev Neurol 2019;15:483-90. (doi:10.1038/s41582-019-0216-y)

17. Varga Z, Flammer AJ, Steiger P, Haberecker M, Andermatt R, Zinkernagel AS, et al. Endothelial cell infection and endothelitis in COVID-19. Lancet 2020;395:1417-8. (doi:10.1016/S01406736(20)30937-5)

18. Headache Classification Committee of the International Headache Society. Classification and diagnostic criteria for headache disorders, cranial neuralgias, and facial pain. 2nd edn. Cephalalgia 2004;24:1160 